fly, and the stable fly. There is a long bibliography. NATHAN BANKS

\section{SCIENCE IN NEW ZEALAND}

The Canterbury Philosophical Institute, New Zealand, has made arrangements for conducting an important expedition to some of the islands in the Southern Ocean. About twenty New Zealand scientists will be taken to the Auckland Islands and the Campbell Islands in one of the government's steamers, and they will remain on the islands for about a week, inquiring into many branches of scientific work. The primary object of the expedition is to enable observations to be made by Dr. C. Coleridge Farr and other investigators in regard to terrestrial magnetism. The time is very opportune for this, because active work in the same field is being undertaken in other parts of the Pacific Ocean. The council of the Canterbury Institute, however, suggested that the sphere of operations should be largely extended. The government of the dominion has fallen in with the suggestion, and a fairly large party will be taken to the islands.

The Auckland Islands lie about 200 miles south of New Zealand, and the Campbell Islands about 300 miles southwest of the dominion. They are visited periodically by the government's steamers, which have provisions on them for shipwrecked mariners. The Campbell Islands are used as a sheep run, but the Auckland Islands are quite uninhabited. Scientists have reported upon both groups on previous occasions, but the coming expedition will make very comprehensive investigations. The principal interest of the expedition centers in the fact that there will be concerted action to obtain further evidence in regard to the old antarctic continent, which, it is supposed, joined New Zealand to South America on the one hand and to Australia, Kerguelen Land, Mauritius, Madagascar, Africa, and the island of Tristan D'Acunha on the other hand. If this ancient continent had an existence, the Auckland and Campbell Islands are probably waifs and strays that it has left behind. This theory has found general acceptance in New Zealand. A mass of evidence has been collected by zoologists and botanists, and it seems to leave little doubt that the antarctic continent once enjoyed a mild climate, that it carried large and extensive forests and other vegetation of a rich, luxuriant, and almost tropical character, and that it was inhabited by a large population of animals, some of which are still represented in New Zealand, Australia and South America. The latest evidence in this direction is the discovery of fossil leaves by a member of the "Discovery" Antarctic Expedition in South Victoria Land. These fossil leaves corroborate evidence that was obtained previously. It is hoped that more evidence will be added by the New Zealand scientists. They expect to leave in the middle of November of this year, and to return in the following month. They will be divided into two parties, one party going to each group. The Hon. R. $\mathrm{McNab}$, minister for lands, has been asked to take the lead, but if Parliament is in session he will not be able to take part in the expedition. The following scientists will join the party :

Auckland Islands: Magnetic observers, Dr. C. Coleridge Farr and Mr. H. D. Cook (Christchurch); zoologists, Dr. C. Chilton (Christchurch) and Dr. W. B. Benham (Dunedin), general zoology; Mr. G. V. Hudson (Wellington), insects; Mr. J. Drummond (Christchurch), ornithology; Mr. G. R. Marriner (Christchurch), general zoology. Botanists, Dr. L. Cockayne (Christchurch), ecological botany; Mr. A. H. Cockayne (Wellington), plant pathology, and Mr. B. C. Aston (Wellington). Geologists, Messrs. R. Speight (Christchurch) and Clark (Auckland). Photographer, Mr. S. Page (Christchurch).

Campbell Islands: Magnetic observers, Mr. H. P. Skey and Mr. E. Kidson (Christchurch). Zoologists, Professor Kirk (Wellington) and Mr. J. B. Mayne (Christchurch), Dr. Hilgendorf (Christchurch), general zoology, and $\mathrm{Mr}$. E. B. Waite (Christchurch), ichthyology. Botanists, Mr. M. M. Lairy (Christchurch) and Mr. D. Petrie (Auckland). Geologists, Dr. Marshall (Dunedin), Professor Jarman 
(Auckland), mineralogist, and Mr. A. Hamilton (Wellington).

JAMES DRummond

\section{SCIENTIFIC NOTES AND NEWS}

THE Silliman lectures at Yale University will next year be given by Dr. Albrecht Penck, professor of geography at the University of Berlin.

THE following have been elected by the council of the British Association to be presidents of sections at the meeting of the Association to be held in Dublin in September next under the general presidency of Mr. Francis Darwin, F.R.S.: Section A (Mathematical and Physical Science), Dr. W. N. Shaw, F.R.S., director of the Meteorological Office; Section B (Chemistry), Professor F. S. Kipping, F.R.S., professor of chemistry in University College, Nottingham; Section C (Geology), Professor J. Joly, F.R.S., Professor of geology and mineralogy in the University of Dublin; Section D (Zoology), Dr. S. F. Harmer, superintendent of the University Museum of Zoology, Cambridge; Section E (Geography), Major E. H. Hills, C.M.G.; Section F (Economic Science and Statistics), Lord Brassey; Section G (Engineering), Mr. Dugald Clerk, M.Inst.C.E.; Section H (Anthropology), Professor W. Ridgeway, professor of archeology in Cambridge University; Section I (Physiology), Dr. John Scott Haldane, F.R.S., university reader in physiology at Oxford; Section K (Botany), Dr. F. F. Blackman, F.R.S., professor of botany in the University of Leeds; Section I (Educational Science), Professor L. C. Miall, formerly professor of biology in the University of Leeds. Invitations to deliver evening discourses during the meeting of the association at Dublin have been accepted by Professor H. H. Turner, F.R.S., Savilian professor of astronomy at Oxford, who will take as his subject "Halley's Comet"; and Professor W. M. Davis, of Harvard University, whose lecture will be entitled "The Lessons of the Colorado Cañon."

THE following Americans expect to attend the Fourth International Congress of Mathematicians, to be held in Rome, April 6-11:
Professor E. H. Moore, University of Chicago; Professor T. S. Fiske and D. E. Smith, Columbia University; Professor G. D. Olds, Amherst College; Professor Virgil Snyder, Cornell University; Professor C. A. Noble, University of California; Professor J. G. Hardy, Williams College; Dr. W. D. A. Westfall, University of Missouri; Dr. C. L. E. Moore, Massachusetts Institute of Technology.

Professor Theodore W. Richards, of Harvard University, has been elected an honorary and foreign member of the Chemical Society of London.

THE gold medal of the Royal Astronomical Society was awarded to Sir David Gill by the Royal Astronomical Society at its annual meeting on February 14, in recognition of his contributions to the astronomy of the southern hemisphere.

Professor George H. Darwin and Mme. S. Curie have been elected corresponding members of the St. Petersburg Academy of Sciences.

Mr. C. M. Conner, agronomist at the North Carolina College and Station, has been appointed assistant commissioner of agriculture for the Philippine Islands.

Dr. August Martin, professor of gynecology at the University of Greifswald, will visit this country next summer to attend the annual session of the American Medical Association.

Professor C. W. Halu, head of the geology department of the University of Minnesota, has been chosen to represent the university at the Pan-American Scientific congress to be held at Santiago, Chili, next December.

Dr. W. N. Shaw, Emmanuel College, Cambridge University, has been appointed to represent the university at the meeting of Imperial and Colonial meteorologists, convened by the Royal Society of Canada, to be held at Ottawa in May, 1908.

Dr. J. P. Rowe, professor of geology in the Univensity of Montana, hás been elected president of the Montana State Teachers Association.

The Montana Academy of Science, Arts and Letters held its annual meeting at Mis- 